Comparative Philosophy Volume 5, No. 2 (2014): 4-24

Open Access / ISSN 2151-6014

www.comparativephilosophy.org

\title{
ALL OR NOTHING? NATURE IN CHINESE THOUGHT AND THE APOPHATIC OCCIDENT
}

\author{
WILLIAM FRANKE
}

\begin{abstract}
This paper develops an interpretation of nature in classical Chinese culture through dialogue with the work of François Jullien. I understand nature negatively as precisely what never appears as such nor ever can be exactly apprehended and defined. For perception and expression entail inevitably human mediation and cultural transmission by semiotic and hermeneutic means that distort and occult the natural in the full depth of its alterity. My claim is that the largely negative approach to nature that Jullien finds in sources of Chinese tradition can also be found in the West, particularly in its apophatic currents or countercurrents that contest all along the more powerful positive conceptions and systems for construing and mastering the natural world. These insights grow especially from the critique of idolatry, in which worship of nature, in concrete, objective forms taken as gods, is negated. Bringing out this negative-theological matrix can give us a perspective on Jullien's treatment and expose some of his own biases notably in favor of immanence to the exclusion of metaphysical transcendence. Comparative philosophy serves in this negative-theological key self-critically to identify blind spots in one's own culture.
\end{abstract}

Keywords: nature, François Jullien, apophasis, negative theology

Nature, in Western literature and art, is by most accounts a figure of open-handed generosity and nurturing. "She" is iconographically represented most palpably and intimately by the nursing breast. Nature, however, can also be epitomized by a cornucopia teeming with every delectable food enticingly placed on display and promising to satiate all comers. This latter image represents her more extraverted side turned toward universal outreach. She beckons to all and sundry, spilling her goods from the wide-open mouth of the "horn of plenty." Mother Nature gives to all freely of her seemingly inexhaustible stores and knows no measure of restraint. At least until recently, her ever renewable resources have appeared in their fabulous

FRANKE, WILLIAM: Professor, Philosophy and Religious Studies Program, University of Macau, China, and Professor of Comparative Literature and Religious Studies, Vanderbilt University, USA. Email: williamfranke@umac.mo 
copiousness to be practically beyond all possibility of depletion. Abundance and productiveness are thus built in at the foundations of the myth of nature. To this extent, the concept of nature naturally presents itself, at first flush, as an eminently positive concept. What we will find, however, is that it is only as negation, as the negative par excellence, that nature can truly serve as universal source and as unlimited resource. Recognizing the intrinsic negativity of nature, moreover, will prove to be the antidote necessary for disabusing us of delusions that we can heedlessly manage and manipulate our environment in accordance with our own selfwilled desires and without first minding and conforming ourselves to nature's silent dictates.

Natura as a figure in medieval allegorical poems like the De planctu naturae by Alain de Lille (Alanus de Insulis, 1117-1203) is a prolific producer of life and letters alike. She pullulates with numberless progeny of material, fleshly things but also generates their scarcely containable significances without stint or limit. Her natural creativity is understood typically through an analogy with language. Things and meanings alike tumble out from the lap of Nature, whose generative powers are fecundated by the creative Word, the divine Verbum or Logos. This prodigious creativity is then further imitated and multiplied by poets through the words of literature. Taking up the relay from Alain, Jean de Meun (1240-1305) in the Roman de la rose continues to elaborate the allegorical representation of Nature and Nature's priest, Genius. Unbound by the normal constraints of convention and culture, Natura and her male counterpart, Genius, writing with his phallic stylus, his "pen," have their own unrestrained capacities of creation or poiesis. They produce both words and every species of being according to its kind, as well as freaks and solecisms. Deviations from proper expression and orthography are placed by these medieval poets, through an inescapable analogy, in parallel with miscarriages of nature. ${ }^{1}$

Monstrosities (literally "showings," as in "demonstrations"), both material and linguistic, render conspicuous some of the intriguing excesses and ambiguities of natural generation: they do so especially when the human penchant for deviancy mixes its own mischief into the process of engendering - for example, by bastardizing pure, noble genealogical lines. The linguistic mode of operation of Nature in this medieval imagining may at first seem to provide another positive way of representing natural creativity - namely, in terms of manifest, familiar phenomena of language. However, it also brings us near to recognition of the negativity at nature's source and origin, since language is inherently negative, engendered by difference, always not what things simply are themselves and as such - in their unmediated simplicity. Tellingly, a negation projected backward from language might be detected in the very notion of simplicity itself. The word "simple" is itself produced by negation: it breaks down etymologically into its Latin components sin or sine (without) and plic (fold). The simple is that which is without folds; it is the negation of complexity, which means being compounded with $(\mathrm{cum}=\mathrm{com})$ or of various foldings (plexi). As such, simplicity is first conceived only in and through language.

\footnotetext{
${ }^{1}$ For ingenious elaboration on this vertiginous topic, see Bloch (1983) and Leupin (1989).
} 
Despite such inherent negativities, nature commonly stands for the manifest, the positively present: it is a cataphatic concept, if ever there was one. We call nature what is immediately at hand, springing up spontaneously-sponte sua-given, or literally birthed (natus) of itself, prior to the transformative activities brought to bear by human agents and their conceptualities and technologies. Is there any warrant for considering what is not, or what withdraws from being and speech, to be in any way natural? Are such elusive non-phenomena or negative phenomena not defined precisely by their being unnatural, by their refusing life, and by their denial of being as it is naturally given to us in the world of ordinary experience?

Representations of nature, even in the West, admittedly, are not uniformly positive. There have been moments in Western tradition expressing a sense of betrayal by nature, for example, Giacomo Leopardi's desperate crying out, from the depths of Romantic melancholia and despair, against "step mother nature" ("la noverca natura") in La Ginestra, although he is only echoing a figure that is employed already at the heart of Roman classicism by Cicero in his De republica. Many have confessed themselves appalled by nature's indifferent destruction or cruelty: Wordsworth's phrase "nature red in tooth and claw" betrays dismay at the ferocious but universal spectacle of natural predation among animals, and Hobbes's "state of nature" recognizes treacherous killing as natural to humans, too. In another key, Voltaire's "Poème sur le désastre de Lisbonne" indicts the perversity of the supposed laws of nature as an "empire of destruction" ("De la destruction la nature est l'empire").

Such expressions capture obvious, undeniable facts of nature, crucial facets of her appearance in the world of phenomenal manifestation. In decadent phases of culture, nature can even become an object of loathing and horror, producing the "flowers of evil" imagined by Charles Baudelaire (Les fleurs du mal, 1857-68). However, beyond any of these richly suggestive and divergent figurations, there is another possible face of Nature, or more exactly an effacement in which nature is what invisibly and imperceptibly encompasses us all. In this case, nature is precisely what never appears as such, nor ever can be exactly apprehended and defined. For perception and expression entail inevitably human mediation and cultural transmission by semiotic and hermeneutic means that distort and occult the natural.

In order to place this cultural mediation under examination and so to take up our distance from it, we are well-advised to travel East. ${ }^{2}$ Certain classical cultures of Asia seem most apt to suggest an original idea of how nature might find its least inadequate image in what does not appear at all and its deepest affinities in what cannot be articulated. Specifically, I propose to take up an observation post overlooking ancient Chinese wisdom in both its classical (Confucian) strands and their (Daoist) dialectical antithesis. This is one location from which we can discover a conception of nature as inherently negative, as the apophatic par excellence.

According to the Chinese conceptions, beneath or within the phenomenal appearances that gaily dance before the windows of our senses as employed in

\footnotetext{
${ }^{2}$ Ames (1989) can serve as a landmark and guide along this itinerary.
} 
ordinary perception, there is something else, something that does not as such appear, an invisible dimension. In traditional Chinese wisdom, however, this hidden reality is not typically thought to transcend nature into a purely metaphysical, indeed an unnatural realm. This invisible dimension is found rather in the immanent inscrutability of things in nature as a process of ongoing, inarrestable change. The phenomenal universe is taken to be the veil of a mystery that has no name or concept, although as the immanent All, it is commonly identified with nature through a great variety of mythological forms of expression.

In dominant currents in Western philosophy, this numinous and fathomless nature has typically been suppressed in order to positively think the all, the universal, the whole. In the West, nature typically was and is taken to be a sub-realm of the whole of being, thus the object of only limited knowledge by lower faculties, particularly the physical senses of sight and hearing, smell and taste and touch. This hierarchical domination has involved suppression also of the apophatic wisdom that shadows Western metaphysics at every step of its itinerary through history. Indeed, the subordination of nature turns out to be an indicator of a loss of sensibility for the apophatic. I intend to expose this history from an eccentric vantage point by following the lead of one of the great contemporary mediators of philosophical thinking between European and Chinese thought, François Jullien. As I construe Jullien's project, the key to it is, precisely, apophatic awareness: this is what places Chinese wisdom on a common ground with certain deep strata in Western thinking, uncovering a fertile field for dialogue that can point indicatively to a dimension that is effectively universal. The question of the representations of nature in the West and in the East respectively serves perfectly to bring out the stakes of apophasis as a miraculous "open sesame" in this encounter between cultures because the characteristic efforts of both cultures clearly show that, taken radically, nature is beyond all possibility of representation.

To begin to pry open this perspective, we can turn to Jullien's analysis of "silent transformations" as apprehended especially in traditional Chinese wisdom as a peculiarly ungraspable form of negation - the type of negation that I will call "apophatic." Jullien (2008) explains the invisible dimension of nature, which has just been invoked, with reference to the process of aging that, though invisible, is nevertheless taking place in every moment and in every part of our bodies and of our entire lives. Aging determines every aspect of our being, working at the surface of our skin but also in our psychological depths. It is continuous and total, and for those very reasons, paradoxically, invisible. While specific phenomena tell of our age, the global fact itself is not as such perceptible and escapes our notice minute by minute, hour by hour, day by day, month by month. Aging operates silently in us and in the end destroys us altogether. However, as such, it escapes our consciousness: we are unaware of its full deployment and ramifications across every aspect of our being . . . all the while that it is going on in us. Only in moments of comparison, for instance, with early photos does the transformation become conspicuous-poignantly, even pathetically so. Jullien is willing to speak here of a "revelation", albeit with a caveat to the effect that he does not mean thereby anything "mystical" in nature. I take his 
analysis of the phenomenon of aging, nevertheless, as exemplary of an applied form of apophatic vision. And whether one considers it to be "mystical" or not, I will maintain that such vision is accessible equally to Western and to Eastern thought.

\section{THE NATURE OF DAO, OR DAO OF NATURE}

The theme of nature as an All that always eludes us is thus, I maintain, a universal question and one that raises the possibility of some kind of relation to a universal philosophical truth from a position in between Eastern and Western paradigms. Among the sources of philosophical reflection in Chinese tradition, the very first composition of the Dao-De-Jing(道德经), which is traditionally attributed to Lao Zi, sixth- to fifth-century B.C., could be taken as emblematic of the book's naturalist vision of an ineffable mystery immanent within all that lives and is:

道可道, 非常道。名可名, 非常名。無名天地之始; 有名萬物之母。故常無欲, 以 觀其妙; 常有欲, 以觀其徼。此兩者, 同出而異名, 同謂之玄。玄之又玄, 衆妙之 門。

The way that can be spoken of

Is not the constant way;

The name that can be named

Is not the constant name.

The nameless was the beginning of heaven and earth;

The named was the mother of the myriad creatures.

Hence always rid yourself of desires in order to observe its secrets;

But always allow yourself to have desires in order to observe its manifestations.

These two are the same

But diverge in name as they issue forth.

Being the same they are called mysteries,

Mystery upon mystery -

The gateway of the manifold secrets.

(D. C. Lau's trans.) ${ }^{3}$

The named and the nameless, the secret and the manifest, desire and its absence, form a unity: deeply the same, they diverge in name as they emerge into distinct being and manifest identity. Even when opposites are distinguished in thought and discourse, they do not definitively separate, but remain each beholden to a deeper or more intrinsic nature in which they are really one.

Accordingly, the Dao has at least two faces, one manifest and one hidden, like the moon, although more deeply or inwardly, it remains still one and the same. Nature is

\footnotetext{
${ }^{3}$ I compare different translations of Lao Zi's Dao-De-Jing, including those by D. C. Lau, Arthur Waley, Stephen Mitchell, and James Legge. The Chinese text is taken from the Legge edition. [In the case of the citations, except in the book titles, "tao" is replaced by the pinyin transliteration "dao" for the Chinese original character '道'.]
} 
evoked, but not under any graspable, definable concept such as the emergent ( $t a$ physis) or the perceptible or sensory (to aistheton), to evoke the Greek concept of nature. Such manifestations belong to it (as does everything whatsoever), but they do not define it; nor do they exclude what is unchanging and withdraws from manifestation. There is no assertion here that there is anything other than nature, but nature itself (in this dimension) is deeply and mysteriously other to all that we perceive and know. The nature of the Dao is to be without nature and beyond nature in any shape or form that we can grasp or name.

Negation of an indeterminate or indeterminable sort is, in this "way" (dao), built in at the very base of nature. Prima facie, nature is a full and robust idea, the epitome of plenty. The Dao is clearly figured as Mother of all things, even though it remains indescribable and formless in itself: it remains itself apart from any such figurable relation with the universe. This is the case again, and in just these terms, in the twenty-fifth composition:

有物混成, 先天地生。寂兮胗兮, 獨立不改, 周行而不殆, 可以為天下母。吾不知 其名, 字之曰道, 強為之名曰大。

There was something undefined and complete, coming into existence before Heaven and Earth. How still it was and formless, standing alone, and undergoing no change, reaching everywhere and in no danger (of being exhausted)! It may be regarded as the Mother of all things.

I do not know its name, and I give it the designation of the Dao (the Way or Course). Making an effort (further) to give it a name I call it The Great.

(James Legge trans.)

Prior to heaven and earth and other binary poles producing change, there is here, just as in Creation myths, something antecedent and without change, in some sense a Nothing from which everything comes. It may be figured, metaphorically, as Mother of all. The maternal images of Dao as nurturing all things are elaborated further in poem 51: "Thus it is that the Dao produces (all things), nourishes them, brings them to their full growth, nurses them, completes them, matures them, maintains them, and overspreads them" (trans. James Legge). And again, in poem 52 we read:

天下有始, 以為天下母。既得其母, 以知其子, 既知其子, 復守其母, 没身不殆。

That which was the beginning of all things under heaven

We may speak of as the "mother" of all things.

He who apprehends the mother

Thereby knows the sons.

(Waley trans.)

The sixth chapter of the Dao-de-Jing also contributes to the figuring of the Dao as a Mysterious Female source, a sort of Mother Nature, immanent and inexhaustible. 
谷神不死，是謂玄牝。玄牝之門，是謂天地根。綿綿若存，用之不勤。

The Dao is called the Great Mother:

empty yet inexhaustible,

it gives birth to infinite worlds.

It is there within us all the while;

Draw upon it as you will, it never runs dry.

(Mitchel trans. spliced with Waley trans.)

Nature, as the ultimate source of all that exists, is at the same time equated here and in Daoist texts more broadly with Nothing, certainly with nothing that can be named or known. The figures of Nothing are persistent and pervasive. Here they appear as an emptiness that is inexhaustible, despite the fact that the notion of a thinking which is a thinking of Nothing also has something that is most unnatural about it. The sense of Nothing here is all-pervading: it is conceptualized in Daoism as a way without content, a way which cannot be said (as we have just seen in the opening line of the Dao-De-Jing 1), and as an emptiness, for example, in a whole range of Buddhist schools and texts. These presumably metaphysical notions of nothingness, if they are metaphysical, are not thought of as exiting from and transcending nature, but as realizing its inherent process and dynamic. Everything that is anything is considered to be part of one All that does not exceed the bounds of the world: it is all still in the end simply natural.

In the West, too, the All has all along been equated also with the Nothing. However, generally this has been so not so much in the mainstream of its metaphysical tradition as in certain of its countercurrents. This idea of Nothing as universal emanating source is developed penetratingly by the negative theology of the ancient Neoplatonic philosophers from Plotinus to Damascius. It is generally to be found, thereafter, as something of a radical fringe in relation to the tradition of orthodox Christian theology that takes it over and builds on it. Such a figure of the Nothing is passed from Nicolaus Cusanus and Jakob Boehme to Hegel and is especially common in esoteric traditions (Magee 2001). Recent revivals and revisitings of Western apophatic tradition have suggested that this supposed marginalization is mistaken and that the Nothing (nothing conceptualizable or knowable) should be recognized as hidden at the core of mainstream Christian theology from Augustine to Aquinas in the West, as well as in Orthodox theology from its Greek origins. ${ }^{4}$

Clearly, China, even in some of the most widely circulated and authoritative expressions of its philosophy, has conceived of nature as the All and of Nothing as the heart of it. There are, of course, significant tensions between Daoist mystical interpretations and Confucian socially pragmatic approaches. Yet they agree in recommending that we harmonize with nature by erasure, or at least moderation, of

\footnotetext{
${ }^{4}$ My own efforts in this direction are found in Franke (2007) and in Franke (2014).
} 
ourselves and our own self-willed activity. Non-action, wu-wei (無為) is the apophatic path that they indicate as an ethical application of this "natural" apprehension of and response to the universe. The action of non-action aims to enable us to move flexibly in alignment with the ebb and flow of nature. Indeed, it is because nature is itself a disappearing act that a negative form of behavior turns out, paradoxically, to be the best way of harmonizing with it.

The negativity of thought and action that adheres to nature does not produce or posit an abstract metaphysical Nothing. It rather releases the ungraspable concreteness of things by removal of conceptual limits and barriers, by letting things be all that they are or can be, even beyond our powers of conception. Nature is most truly defined, not by anything that it is, but only by what it is not. This is the kind of negativity associated, for example, with something tasteless. Insipidness is the negation of any strong flavor or distinct character. Yet the relative nothingness of the insipid is inhabited potentially by every nature that could be positively perceived as a determination in a given register of sensation. This is the negative in the sense of the neuter. Such neutrality can lead us beyond determinate sensation into a more mysterious kind of negativity at the heart of nature itself. For Jullien, this is an immanent form of negativity, as he maintains especially in interpreting the Yi-Jing (易經) (Jullien 1993).

According to reigning stereotypes, following nature and harmonizing with it is the way to fulfillment in the philosophy of the East, whereas the West typically takes the opposite view, striving to escape or, most often, to master and contain nature. However, these generalizations can be tested and probed and put under pressure until they metamorphose and turn into their opposites. Whenever Western tradition is seen in the light of apophasis as its deepest thinking, true mastery is always found only in the surrender to Nothing at the core of an all-encompassing Nature that cannot be adequately named in this way or in any other. Such has been especially the apophatic logic that counterpoints Western thought all along its way through history, for

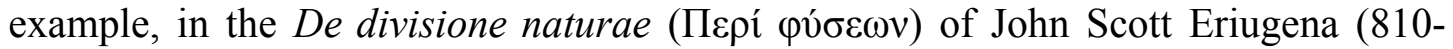
877). What is meant here, however, is not primarily Nothing in a strongly abstract, metaphysical sense. Let us begin by following Jullien's investigation of nothing rather in the neutral sense simply of blandness as he derives this notion from Chinese sources, working in the gap ("écart") between Eastern and Western cultures.

\section{IN PRAISE OF BLANDNESS: LITOTES OF THE NEUTER}

In order to gain a first, global impression of the purport of Jullien's philosophical vision and its overriding message, specifically in terms of the peculiar logic or illogic of negativity, it will be instructive to turn to his little treatise on blandness (Jullien 1991). This work synoptically encompasses his seminal insights in an accessible and paradoxically poignant manner. Its outlook and overview can serve for a preliminary probing of the connections between Nature, Nothing, Immanence, Universality, and Originality in an apophatic perspective. 
The bland (in Jullien's French "le fade") seems, at first, to be merely negative: it lacks any distinguishing quality. Yet this apparently neutral condition can turn out to be the most potent and productive condition of all: it is potentially all qualities, and it can be them in an indeterminate and infinite way. Combined with a little imagination, there is nothing that the bland cannot become, for there is nothing that it excludes. With no distinctive property of its own, it is open in all directions and can be the basis for suggesting every other quality into which the neutral receptivity to any quality could evolve. It is without limits. The bland transgresses the law of the excluded middle: it becomes rather an all-inclusive middle confounding all logical oppositions and antitheses.

As Jullien presents it, in relaying ancient and perennial Chinese wisdom, in which the tastelessness of water is exemplary, the bland absorbs every other quality or savor that could possibly contrast with it in its own amorphousness and consequently infinite potential for expansion. It is in all savors and is, at least potentially, their truth. It expands dynamically on a horizontal plain without requiring any vertical, metaphysical break-through to some other order of reality. It is a dynamic infinite that is constantly in act and knows no stable, achieved state of completeness: its completeness and perfection remain part of an infinite, ongoing process from which no abstraction need or can be made.

One suggestive vocabulary for this neutral state of blandness is that of the neuter. Blandness, in the sense that Jullien derives from many centuries of Chinese literature and landscape painting, as well as of critical commentary and theoretical reflection on art and music, compares closely with the idea of the neuter as expounded by Maurice Blanchot and Roland Barthes. ${ }^{5}$ These authors, among others, have pursued kindred insights in the margins of Western aesthetic philosophy and reflection. My claim is that the natural and yet negative forms of thought that Jullien finds in the East have been gestated also in the West, particularly in its apophatic currents developing especially from the critique of idolatry, in which worship of nature, in the form of concrete objects taken as gods, is negated (Halbertal 1992). Bringing out this affinity can give us a perspective on Jullien's treatment and expose some of his own biases. Such a procedure is meant to further the self-critical process by which apophatic thinking remains in evolution, thinking always also against itself.

At the end of his book, Jullien characterizes "blandness" in Chinese thought and culture as a sort of immanent transcendence active at the root and center of the whole process of reality: it does not open upon "another world", and it dispenses with "faith":

Ni simple litote ni fadeur affectée (ou conduite à se compliquer) l'insipidité chinoise, celle que symbolise la limpidité de l'eau 'à la base de toutes les saveurs', est une conversion dont l'au-delà est en elle-même : conduisant la conscience à la racine du réel, au centre dont découle le procès des choses, elle est la voie de l'approfondissement (vers le simple, le naturel, l'essentiel), du détachement (loin du particulier, de l'individuel, du

\footnotetext{
${ }^{5}$ Barthes (2007). On this pervasive motif in Blanchot, which is diffused throughout his mature works, see Bident (2004), 13-34.
} 
contingent). Sa transcendance ne débouche pas sur un autre monde, elle est vécue sur le mode même de l'immanence (pris dans cette perspective, les deux termes cessent enfin de s'opposer). La fadeur est cette expérience de la 'transcendance' réconciliée avec la nature-dispensée de la foi. (127)

Neither simple litotes nor affected blandness (induced to complicate itself), Chinese insipidity, that which the limpidity of water 'at the base of all savors' symbolizes, is a conversion of which the beyond is itself: conducting consciousness to the root of the real, to the center from which flows the process of things, it is the way of deepening (towards the simple, natural, essential), of detachment (far from the particular, the individual, the contingent). Its transcendence does not enter upon another world but is lived in the mode even of immanence (taken in this perspective, the two terms cease finally to oppose one another). Blandness is this experience of 'transcendence' reconciled with naturedispensed from faith.

Part of my purpose here and in other engagements with Jullien's thinking is to probe the possible "parti pris", or biases, and the discernible "atavisms" lurking within these lucid judgments. ${ }^{6}$ It is important to bring reflection to bear on what otherwise might represent imperceptible automatisms hailing from what remains as unthought in the shadows of this otherwise brilliantly illuminating thinking. In particular, this concluding statement is arguably slanted by Jullien's own anti-clerical prejudices, along with those of French lay culture generally, against any type of religious faith or otherworldliness, especially those characteristic of Christianity.

Jullien embraces a form of immanent transcendence within the real rather than of transcendence to a reality beyond. He finds the solution to the impasses of Western metaphysical thinking, nevertheless, in what purportedly, at least in an initial moment of representation, is the wholly other thinking of the ancient Chinese Orient. He has been criticized by certain fellow sinologists for this use of Chinese cultural capital converted into his own currency of Western philosophy and inflated by the exoticism of the other. ${ }^{7}$ To demonstrate the purportedly alien nature of Chinese thought, Jullien typically starts from examples of Western thinkers, like Hegel, who could not really appreciate a value in Chinese culture such as blandness, which is distinguished only by what it is not. For Hegel, Confucius's "insipid" prescriptions lacked all speculative content and did not say anything that attained to the genuinely philosophical (Jullien 1991, 12). Even Roland Barthes, after his Chinese voyage in 1975, lacked confidence that "blandness" (dan 淡) could really be the right word for the most revered quality in ancient Chinese art and literature and culture and, accordingly, suggested that the Chinese word might be better translated as "peacefulness" (ibid., 10-11).

Eulogizing insipidity is, of course, a reversal of normal, or at least prevalent, values ("renversement generalisé des valeurs", ibid., 23). It is purposefully undertaken, according to Jullien, in order to "evoke the essential". Blandness is not

\footnotetext{
${ }^{6}$ The terms within scare quotes are often repeated in Jullien's own oeuvre and were among the signposts adopted for the 2013 CERISY colloquium staking out the contemporary import of his work.

${ }^{7}$ Billeter (2006). I treat this issue in greater detail in "Universality in the (Apophatic) Gap between China and the West" (forthcoming).
} 
exactly a quality, not a distinct one at any rate, but in some sense the open possibility of all qualities - the capacity for being perceived as any specific quality and as all such qualities potentially. As such, blandness turns out to be much more essential than any given taste or flavor, however intense and exalted. For it is not definable or delimited. It is infinite. Every specific quality in some sense manifests a particular transformation of this indistinct but universal capacity to be something definite and distinct that is the peculiar virtue of the insipid: it is infinitely transformable, and there is no particular savor or quality that it excludes. It is the universal medium in and from which every savor emerges. It is the magma of their transformation from one into another, knowing no bounds itself. We have already suggested that blandness is a kind of neuter in the vocabulary of Blanchot and Barthes, and Jullien does, in fact, borrow this term. Insipidness, so construed, eliminates boundaries and barriers, so that everything flows into everything else. This type of unblocking can be imagined most readily for a spectrum of tastes and colors, but it is not restricted to any given field of objects: it opens into a general promiscuousness of all with all in a kind of universal, mystic union. Here the vocabulary of the mystical used by Western writers such as Novalis may not be to Jullien's taste or liking-just as it was sometimes suspect for Blanchot and Barthes. And yet it, too, has some pertinence, at least if it is heard apophatically as opening out beyond all its own merely heuristic conceptual boundaries, since nothing should in principle be excluded from this universal vision.

Jullien's purpose is not to drive all things together in mystic union or consummation so much as to deploy the insipid and its praise in carefully, concretely delimited, pragmatic social contexts, where it can operate with surpassing efficaciousness. Not a rigorous spiritual asceticism, but rather total engagement with the world, is the goal: "It is not a matter of a morality of solitariness, of living withdrawn from the world, because its lesson is valid first on the political plane and concerns management of one's affairs" ("Il ne s'agit point là d'une morale de solitaires, vivant retirés du monde, car la leçon vaut d'abord sur le plan politique et concerne la gestion des affaires", 26). In the state of indifferentiation and indeed of indifference, in the sense of being without partisanship, the spirit conforms to the underlying state of things beneath all invidious distinctions and definitions.

Even in allowing for an underlying reality of things astir within or beneath the surface evidence of the manifest, there is still no overarching Sense of things to be discerned beneath them (107). It is just that all things transcend themselves in the inarrestable flow of time. Instead of producing the tension of allegory, in which signifiers tend towards a final sense that must be deciphered by consciousness tensely charged with concentration, the insipid for Jullien does the opposite: it "discharges" consciousness ("Elle décharge la conscience", 107). In this manner, blandness undoes all transcendent meaning, exposing it as myth. Its "transcendence" is completely natural, as the final chapter of the book (c. 15: "La transcendance est naturelle") endeavors to demonstrate. 


\section{TRANSCENDENCE AND IMMANENCE OF THE $D A O$}

However, simply opting for immanence over transcendence is not adequate either; it is still based on a logic of exclusion. Even those writing ostensibly against theology often acknowledge this. Theodor Adorno points to this dialectic in remarking that immanence, however necessary to all expression of anything transcendent, if absolutized, is itself, in effect, divinized: "No absolute can be expressed otherwise than in topics and categories of immanence, although neither in its conditionality nor as its totality is immanence to be deified." ${ }^{\prime \prime}$ Adorno wishes to rule this possibility out, but for apophatics divinity is not to be ruled out: it haunts the limits of thought and saying. In order to keep this possibility in play, we might productively counterpoint Jullien's anti-Christian perspective on Chinese tradition with that of a Christian mystical writer. There has, after all, actually been a continuous stream such interpreters of Chinese classical tradition since the sixteenth-century Jesuits.

In Thomas Merton's perspective, whether as the metaphysical Dao of the Daoists or in its more ethically oriented form as Confucianism, classical Chinese thought is based on a transcendent nature or principle of order and harmony (Merton 1967). The thrust of Lao Zi's thought is to recover the innate goodness of nature in a state prior to society and reflection, which is inevitably corrupt. ${ }^{9}$ Principled humanity and moral righteousness, in this perspective, are already degenerate forms symptomatic of a state of decline from the Dao. Social virtues of filial piety and paternal affection appear only when natural, spontaneous relations of harmony have already been lostas Lao $\mathrm{Zi}$ states most explicitly in a few lapidary verses in chapter 18 of the Dao-DeJing.

Lao Zi's Daoism envisages something like an Edenic existence, which, from a social point of view, is anarchic. Concerned chiefly with humanity in a state of society, Confucian thinkers often considered Daoism impracticable and sometimes even deleterious, to the extent that it undermines the authority necessary for social cohesion.

The doctrine of Kong Zi (Master Kong, or "Confucius," as Latinized by the Jesuits) is based rather on faith in humanity (ren 仁), or on the Dao immanent in human nature. It is rooted in a social class, the cultivated military aristocracy $(j u)$ and their six talents (charioteering, archery, music, history, numbers, and ceremony or ritual). It undoubtedly still has something of a transcendent mystery about it: from the Dao, human order springs in ways that cannot be fully comprehended. Nevertheless, these skills can (and must) be consciously cultivated. Whereas Lao Zi's ideal was the uncut block before the sculptor began carving it, Kong $\mathrm{Zi}$ considers how to shape the individual who can build and participate in a harmonious, well-ordered society. Everything depends on being in harmony with heaven and on "visible expression of

\footnotetext{
${ }^{8}$ Quoted from Franke (2007), vol. 2, 269.

${ }^{9}$ Both transliterations, "Lao Zi" (Jullien) and "Lao Tzu" (Merton), in the Pinyin and Wade-Giles systems of Romanization respectively, have wide currency and must be recognized. [In this journal, the Pinyin system is adopted.]
} 
the hidden reality of the universe" through rites, or $L i$ (礼) (Merton 1967, 60). Rather than the inscrutable, incomprehensible Way of the Daoists, in Confucianism and specifically in The Great Learning (Da-Xue, 大學) “the real, the ethical Dao, is celebrated, solemnized, and clarified by rites." Yet precisely the religious or spiritual basis of Confucian social morality is brought out through this emphasis on rites: "Thus, moral action is at the same time contemplative and liturgical. Symbolic ceremony gives morality a character of deeper realization. The Confucian ethic is not only not automatic, not the product of inert routine. It is more than merely spontaneous. It is the fruit of spiritual awareness" (Merton 1967, 61).

The emphases on immanence and on transcendence, as found in Jullien and in spiritual writers like Merton respectively, are not to be set against each other but rather to be held together in tension. Both are actually in agreement on the mutual dependence or co-implication of transcendence and immanence. What we need to probe critically and finally explode are the exclusionary myths that, nevertheless, adhere to any particular path of thought and that limit our capacity for understanding and empathy. Such is exactly the spirit of the Dao, furthermore, as expounded by many who can approach it through their own native language. Among them, Longxi Zhang (张隆溪) emphasizes the Dao's straddling transcendence and immanence precisely by its ineffable or, I would say, apophatic character:

According to Laozi the philosopher, dao is both immanent and transcendent; it is the begetter of all things; therefore, it is not and cannot be named after any of these things. In other words, dao is the ineffable, the "mystery of mysteries" beyond the power of language. Even the name dao is not a name in itself: 'I do not know its name; so I just call it dao.' 'The dao is forever nameless.' Laozi makes it clear that the totality of the dao kept intact only in knowing silence; hence this famous paradox that 'the one who knows does not speak; the one who speaks does not know. ${ }^{, 10}$

Zongqi Cai (蔡宗齐) similarly advocates a “nondualistic" understanding of the traditional Chinese thinkers" approach to "ultimate reality" as "ultimate Process" that spans both the immanence and transcendence of nature and humanity: "The early Chinese worldviews . . . entail either a 'naturalization' of conscious beings in the numinous realms . . . or a 'supernaturalization' of actual processes in the world of nature and man (the cosmological li, Confucius' Dao of human history, the allinclusive Dao of the Changes)" (2002, 107). In either case, the natural and the supernatural or transcendent-of-nature are actually inseparable and cannot be conceived except in relation to one another.

The Nothing on which even blandness pivots does have something transcendent about it, though not to the exclusion of immanence, especially not of total immanence. Yet such total immanence transcends itself and can no longer be adequately conceptualized as only or exclusively "immanence." The idea of absolute

\footnotetext{
${ }^{10}$ Zhang (1992) quotes and translates the Dao-De-Jing from the Chinese edition, Lao-Zi-Zhu [The Annotated Lao Zi], with the commentary of Wang Bi (A.D. 226-49).
} 
transcendence cannot be excluded from it either. Immanence as such absolutely transcends every possible conception of it. Total immanence is without confines and involves or contaminates everything, transcending all limits. Even what the imagination of a transcendent God as Creator is aiming at cannot be categorically divorced from the infinite immanent-transcendent energy of the Dao. The theistic notion of God is inadequate as a representation, but so are all representations. And the theistic notion does serve to capture certain nuances of the feeling of absolute dependence (as Schleiermacher showed in Der Christliche Glaube, 1830): it may in some respects express the unconditional contingency of all that exists as created from nothing (creatio ex nihilo) better than other images can do. It is not adequate to pin the label "nature" to everything, as if that summed it up and let us know its true and abiding or essential being. All, nature, must rather be admitted to be a great unknown and, as such, to master us together with everything else-hence Deus sive Natura. A variety of images and approaches, even ones that in word and expression are mutually opposed, are necessary and in any case are persistent in human beings' efforts to relate to this unknown. Such plurality proves necessary in Chinese as well as in Western cultures, with each displaying their inexorable and inextricable polarities. Only the multiplicity of perspectives enables us to approach the absolute of having no perspective at all.

\section{MENCIUS, OR THE NATURALNESS OF MORALITY: IS THE ALL WITHOUT TRANSCENDENCE?}

In a paradigmatic case that is outstanding for its philosophical coherence and rigor, the thought of Mencius (372-289 B.C.) is taken by Jullien to be worldly and merely human, emphatically without transcendence (Jullien 1995, 88). It is based, rather, on humanity in the sense of being connected with others (85). Nonetheless, humanity and its harmony are connected with the total regulation of the world, which flows from a source beyond any of its manifest forms or phenomena. The connection between and the order among all things is not simply a thing alongside others in the world. It eludes any inventory, however exhaustive, of the discrete things that make up the world. This order and connection of things is necessarily infinite, given the nature of the temporal world as open and evolving. Jullien acknowledges here a connection with "transcendence," which he conceives of expressly as the absolutization and totalization of immanence (173). Yet he insists that this has nothing to do with mysticism or the ineffable (82): as an immanent ordering, it has no relation to divinity. I submit, nevertheless, that such unlimited connectedness is a perfect incarnation of divinity in the negative sense in which no identities or representations can be adequate to the divine, even while all such representations might serve to bring about or foster unreserved openness to the universe and to life as a whole as exceeding our comprehension.

The sources of Chinese wisdom, as Jullien expounds them, open to a dimension of the infinite and inexhaustible that exceeds all human power to understand or even to conceive of it. Such wisdom in crucial ways thus approaches the theological 
dimension that apophasis attains by negation of all propositions concerning God. In Mencius, by Jullien's own admission, morality is an unconditional ideal ("idéal inconditionné", 45) that is manifest only very partially in actual human comportment. It is the unmanifest of our human nature. It never appears in or as itself but always only in tendencies and approximations. Yet it is not just a mechanism for regulating our egoisms and their conflicting desires. It belongs rather to the fulfillment of our persons, or to the perfection of our natures, and it lies embedded in our natures beneath the level of conscious choice and control.

To this extent, Mencius turns out to be actually close to Rousseau and Kant, inasmuch as he perceives morality as rooted in something anterior to experience-in something innate or a priori. In Jullien's words: "To found morality is thus to find for it a rootedness that is anterior to and renders it independent of experience-in our natural inclination (Rousseau) or in the a priori of practical reason (Kant). Mencius cannot but be ranged alongside them: he is first in China to define the category of the original [foncier] and innate" (45). There is, for Mencius, a natural disposition to morality, an inherent goodness in humanity. This seems to be an invitation to embrace a purely humanistic ethical ground, and yet by thinking the human radically as without any assumed frame or foundation, this natural disposition becomes not only that but open as well to its own Other. This interface with alterity is what is more vividly figured in the divine Voice of conscience by Kant and Rousseau.

There is, for Mencius, as Jullien reads him, no external or personal "voice" of conscience, as there is for both Rousseau and Kant. And there is in Mencius no moral imperative as such but rather just an inborn feeling. Jullien emphasizes that, for Mencius, moral conscience is manifest in our spontaneous reactions, for example, the natural impulse to prevent a child from stumbling into a pit, or the emperor's stopping a sacrifice out of pity for the terrorized bull being led as victim to the slaughter. This is simply a natural prompting of sympathy, not an actual injunction. Heaven, in the Chinese classic tradition, does not speak (Jullien 1995, 43-44). As the Mencius famously affirms, "Tian does not speak - it simply reveals through deeds and affairs" (5A5). Jullien interprets this to mean that natural reactions of pity reveal a norm and an absolute in its last manifestation or "tip" ("bout"). In fact, this type of instinctive repulsion is only incipient and inchoate, not explicit and articulate: it is just the beginning of a sentiment that needs to be developed and cultivated into full-fledged "humanity" (ren 仁). The impulse as such is inconstant and is soon forgotten. Yet it alludes to something natural, potentially all-pervasive, and even (I maintain) transcendent - coordinated with "Heaven."

Jullien concludes that heaven is a principle of harmonization internal to the cosmos rather than a Will imposed from without by a Creator (Jullien 1995, 52). The absolute is conceived simply as a "regulated process" ("processus régulé", 53), and Mencius reflects on man's relation to this process. We can correspond to it, but we cannot control it, nor even define it. There is indeed an unconditioned and absolute basis for morality, yet it is approachable only indirectly or negatively. In this case, Mencius turns to reflection on human conduct rather than to speculating on the nature of reality per se: like Socrates, Mencius deflects thought from "speculation on the 
march of the world" to "reflection on his own conduct" (53). It is only through regulating one's own conduct in quotidian life that one gains access to or becomes conscious of the transcendent principle, the Way, that governs all things in their evolution. Cosmic regularity is experienced day by day in ourselves as an inherent normativity of what is good for us.

Nonetheless, Jullien takes all this in a rather exclusively humanistic sense. His eschewing of the role of religion in classical Chinese thought can be placed in the lineage of Marcel Granet. Granet's categorical exclusion of theology from Chinese wisdom is summed up in his statement that Chinese wisdom is entirely human and owes nothing to the idea of God ("La sagesse Chinoise est une sagesse indépendente et tout humaine. Elle ne doit rien à l'idée de Dieu," Granet 1999, 478).

However, in reality, God cannot be made to fit into an idea, and no idea of God can be more than heuristic. Moreover, and for the same reason, it may be inexact and reductive to circumscribe wisdom as merely "human." Granet is certainly right that in China religion is not a "differentiated function of social activity" (476). In its most authentic forms anywhere, religion does not "exist" as such distinctly: nevertheless, it informs everything. The truth of religion is never a separate institution or practice or consciousness but rather what informs and ties together all aspects of life. This is the subtler awareness of religion that the apophatic approach has all along been trying to foster and restore also in the West. In this spirit, I defend traditional forms of religion as often our best poetry: they can serve to forestall forgetting of the Nothing that is not objectively manifest and yet is the heart of all everywhere, and that as ineluctable negation wounds and thereby ties us all together. ${ }^{11}$

Like Granet, Jullien (1995) insists that Confucian regulation, which is the foundation of this teaching, is without any basis in religious revelation. The coherence to which it is attuned is that of the total immanence of nature (276). However, when revelation is nothing positive but rather an opening to what no formulations whatever can grasp, then even revelation is not to be excluded from this vision. Jullien himself emphasizes that every minute particular can "reveal" the general and bind or tie us to totality ("nous relie à la totalité"), whether that of Heaven or of the Sage ("celle du Ciel, celle du Sage", 276). Granted, rather than aiming at transcendence, Confucius's words treat things as indices of the ground of immanence ("fond d'immanence", 276). There is an immanence working through reality, and this is "Heaven": it has a kind of height of transcendence, but not as exterior to humanity. Instead, such transcendence is nothing but "the totalization of immanence on the scale of the whole world" ("la totalisation de l'immanence à l'échelle du monde entier", 280).

Mencius's Sage, like Confucius's, is apophatic, or without words; in fact, his saying is not a saying ("le dire de Mencius, en fait, n'est pas un dire", 280). His goal is also to be without perspective or bias, so as to react to the natural course of things by a purely immanent logic and without any arbitrary impositions of his own. Such is

\footnotetext{
${ }^{11}$ Franke (2014). In a kindred project, Hass (2013) gives a wide-ranging interpretation of an epochal shift from One to Nothing as opening out beyond all possible reach of enframing paradigms.
} 
his attunement to the natural regulation of the universe. There is a belief here in the harmony of the whole. However, is that not already itself something religious in the sense that counts most? Is it not a belief in what binds all together-literally religio - in a common world? Granted, such sagacious reasoning entails no figure of God as a personal Being. Nevertheless, in an apophatic perspective, it is already clear from the start that no such figures can possibly reveal the ultimate truth of religion. To this extent, Chinese wisdom reveals, in especially transparent terms, what religion as understood in its core suggests and portends: an erasure of all our finite figures in order to expose something infinite that they conceal at the same time as they reveal it. This cannot, then, be taken as an exclusion of metaphysics or a reduction of religion to ethics. It rather helps to clarify what the poetry of metaphysics and theology are really about - namely, relating all together in a harmonious common order. The idea that the "principle" of it all, "God," should already be perfect apart from any of his self-manifestations in the world is affirmed likewise of the Dao: the Dao was formless and perfect or complete in itself before the universe began (Dao-De-Jing, chapter 25).

The perfection of "Heaven" is indeed a cardinal postulate consistently affirmed throughout the Confucian classics as well. Zhong-Yong (中庸), chapter 26 is a locus classicus stressing the permanence and infinity of the way of the universe. And this is, after all, the essential meaning of divine "transcendence." Not that the divine can be opposed to the world as something else. Yet neither is divinity dependent on the world or conditioned by the world's imperfections. And any conception of it in worldly terms, even in terms of the world's own self-transcendence, is also a misconception: Heaven, like God, can only be miraculously and paradoxically misconceived. The Dao is also said to exist before and without the world. It exists "before Heaven and Earth" and "stands on its own" (Dao-De-Jing, chapter 25). Our only means of representing it are poetic. Then why not represent the principle of things as effecting an act of Creation - and why not then as a Creator, for good imaginative measure? These are not images that retained currency in Chinese classical wisdom, but as images they come from the same negative apprehension of unity as do the Chinese figures of interdependent poles_yin (阴) and yang (阳) — and the imagination of a totally, inconceivably immanent-transcendent Way.

Jullien's point is often how different this is from Western, transcendentalist representations of moral consciousness. My point is that beyond the representations there is, in any case, a common ground in the unrepresentable. "Heaven" (Tian 天) is ultimately a representation for this source of regulation which, however, is not accessible except through its effects. It is not as such an object of knowledge. Like God, it can be described only indirectly. There is a difference in the choice of representations. But it is a difference within a common basis or "fund" of understanding (Jullien's "fonds d'entente") at the level of the unrepresentable. There are important differences in the way that the governing and energizing Power at the source of the universe is represented, but the representations are in any case only heuristic. 
A goal of Mencius's reflection is to affirm, as the last chapter of Jullien's book itself announces, that "moral consciousness gives access to the unconditioned" ("La conscience morale donne accès à l'inconditionné", 164) or to what in Chinese tradition figures as "Heaven" ("Le Ciel"). Jullien conceives of this not as a religious and certainly not a theological dimension, but again these are differences of imagery, not of the nature and intellection of the relation to an absolute that relativizes our every thought and action.

What is missing in China is not at all the sense of everything being tied together in one and of the perfection of this conjunction in the Way, and thus of all things as existing in relation to All in responsible reciprocity grounded in a common source. Some such vision and conviction is the basis of religion in almost any culture, and it is every bit as strong in China as in the West. Only the institutional and even conceptual and imaginative forms of religion characteristic of the West are missing from Chinese classics and culture. But these forms and expressions are all only expressions and even disguises of a more authentic religion, when not outright perversions and betrayals of it. Of course, institutional forms and public practices can also be authentic mediations of religion, but they are in any case not necessary and inevitable so much as culturally relative-even in being about the absolute. The thesis that Confucianism is not a religion and that religion as such is foreign to Chinese thought and culture is correct if and only if one adheres to a certain positive definition of religion. Seen in terms of negative theology, the genuinely religious is always what is not and cannot be explicitly formulated in any of the articulations that are commonly labeled and analyzed as "religious." The essence and inspiration of religion is itself not properly "religious." It cannot be characterized or formulated adequately or properly in any language.

Chinese wisdom is seeking and recommending a more radical commitment to a view of the wholeness of life and of our belonging to the overall process of things. One could take this as a purely ethical commitment, but not in a sense that would allow it to be cordoned off from religion. In fact, Jullien remarks that the notion of the "Way of Heaven" (Tian-dao 天道) is first introduced into Chinese thought, during the Shang dynasty in the second millennium before Christ, as a "Lord on high" (Shangdi 上帝) - thus in terms very near to those of a personal God. The Way is at this stage a "mandate" or command conceived of as coming from a sovereign (54). But Jullien stresses that this "absolute factor" ("facteur absolu") is progressively depersonalized to a function of engendering and transforming. From near the inception of the Zhou dynasty a little more than a millennium before Christ, the figure of a personal God disappeared from the Chinese universe.

This "progress" could be considered one of becoming less beholden to myth, but it can also be considered simply as reflecting a lesser development of - or indulgence in - the imagination for rendering the experience of regulation in the world, which becomes a spontaneous natural process rather than a personal and willed creative act. These latter theistic and revealed forms of apprehending and relating to the regulation of the universe might indeed capture other, further possibilities for imagining the mystery of the relationship between the world and its imaginable source. For Hegel, 
they represented "higher", more evolved modes of religious consciousness. In any case, all aspects of reality must be admitted to be subject to this universal regulation. What seems to be so limited about theism, specifically from the point of view of the imagination, is that it apparently reduces the universe to human measure, construing its supreme principle as a divine Person made in the human image. However, theism, when conceived of through negative theology, can also cut in just the opposite direction, so as to undercut the human and expose it to a divine measure - that is, to the radically Other. The true person is not what we know in human beings: they are only a limited form of personhood making manifest in a corrupt guise the power or energy that sublimely infuses the universe beyond our comprehension. God is ultimately, in "his" own being or Godself, the not-personal, but this must still be thought of from the basis of, and as not excluding, personality. Thus the regulation of the universe, if it is not just a machine or purely vital force, must also be thought along lines that include rather than exclude personal will, consciousness, etc. And these are all so many invitations to the imagination - ones that can hardly be refused, unless we choose to construe our personal and moral beings in purely mechanistic and vitalistic terms.

There is a tendency, registering clearly in Jullien, to deem Chinese cosmology to be sublimely free of all the metaphysical baggage of intentionality and caring and consciousnesss. But such a cosmology leaves much of the real in its many possible dimensions as yet relatively unimagined. The great poetic potential here has been exploited in the West, signally in its theological epics ranging from the Divine Comedy to Paradise Lost and further to Tasso's Gerusalemme liberate and Blake's Jerusalem and even to Joyce's Finnegans Wake. ${ }^{12}$ The lack of metaphysical and theistic figures in Chinese classical wisdom is an unambiguous advantage only if one thinks one knows what the universe really is and that it is like a mechanism, or perhaps like spontaneously living nature, but in any case not like a person. Yet claiming to have such knowledge is more presumptuous than leaving open the ultimate nature of the universe and rather exploring imaginatively to their limits all aspects of experience. This involves imaginatively exploring the whole panoply of forms in which cultures have imagined reality, and so also all forms of religion.

Religions are all so many ways of entering into relation with the source of "regulation" envisaged by Chinese wisdom. A fully deconstructed version of Western tradition finds in the Chinese tradition, in its being without epic and revelation (as Jullien stresses), confirmation of precisely what these forms were persistently aiming at and yet always failed to encompass and so to reduce to the word-all the West's epic attempts and rhetorical revelations notwithstanding. The Chinese approach undergoes perhaps less of an imaginative elaboration and conceptual detour in its illuminating or pointing to what is simply beyond the verbal. Yet in Chinese and in Western apophatic wisdom alike, the purpose of representation is not to lay down definitive truth but rather to point as an index to the Way or Truth that lies beyond saying. This, moreover, is the necessary premise for any possible intercultural

\footnotetext{
${ }^{12}$ I undertake such a reconstruction of Christian epic tradition in Franke 2009, Part 2.
} 
understanding. This possibility, in which the particular discursive forms of various cultures need to be bracketed, is based on what Jullien likes to call the "fonds d'entente"-something in the background that "funds" common understanding, a resource to be drawn on in dialogue, one rendering possible the divergences and convergences between patterns of thinking characteristic of different cultures.

Jullien takes Confucianism to be pure morality without religion (91). Nevertheless, its wisdom has served to point beyond the field of representations that he generally identifies as "religion" to the unrepresentable Source or Way in which the separate identities that divide things from one another are abolished or at least suspended. This corresponds also to what Western wisdom sometimes recognizes as the apophatic. Not any human act of morality, but rather doing nothing on our own initiative and positing nothing merely of our own invention, is the only principle of morality in this understanding of both Daoist and Confucian ethics. Our part is fulfilled simply in following and enabling the natural propensity of things to take its course (Jullien 1992). The hard thing for us is not to interfere and thus not to block the flow of energy and life from their source. The whole strategy of Chinese wisdom is to gain access to the source of all by removing human limitations as so many obstacles to its full and unencumbered self-deployment. One does not have to have the truth or the right way oneself but simply to let the Way be itself and become our way. It can even become the one and only Way negatively - as the negation of all of our ways (cf. Isaiah 55: 8-9). Diverging from Jullien, I present nature in the Chinese conception not so much as a fundamental alternative to theistic conceptions of divinity but rather as a different and more consistently apophatic way of approaching an abyssal mystery or enigma (for finite human understanding) at the source and foundation of all reality. One of these human approaches to value and meaning that transcends our comprehension and summons our capacities to their limits passes through morality and its sovereign dictates or promptings. Another such path pursues the making of poetry in its unaccountable, uncanny inspiration.

\section{REFERENCES}

Barthes, Roland (2002), Le neutre: Cours au Collège de France (1977-78); trans. Rosalind E. Krauss (2007), The Neutral: Lecture Course at the Collège de France (1977-1978) (New York: Columbia University Press).

Bident, Christophe (2004), "The Movements of the Neuter", in Leslie Hill, Brian Nelson and Dimitris Vardoulakis (eds.), After Blanchot: Literature, Criticism, Philosophy (Newark: University of Delaware Press).

Billeter, Jean-François (2006), Contre François Jullien (Paris: Éditions Allia).

Bloch, R. Howard (1983), Etymologies and Genealogies: A Literary Anthropology of the French Middle Ages (Chicago: University of Chicago Press).

Cai, Zongqi 蔡宗齐(2002), Configurations of Comparative Poetics: Three Perspectives on Western and Chinese Literary Criticism (Honolulu: University of Hawai'i Press). 
Callicott, J. Baird and Ames, Roger T. (1989), Nature in Asian Traditions of Thought: Essays in Environmental Philosophy (Albany: SUNY Press).

Franke, William (2007), On What Cannot Be Said: Apophatic Discourses in Philosophy, Religion, Literature, and the Arts, 2 vol. (Notre Dame: University of Notre Dame Press).

Franke, William (2009), Poetry and Apocalypse: Theological Disclosures of Poetic Language (Stanford: Stanford University Press) .

Franke, William (2014), A Philosophy of the Unsayable (Notre Dame: University of Notre Dame Press).

Granet, Marcel (1934; 4nd edition 1999), La pensée chinoise (Paris: Albin Michel).

Halbertal, Moshe and Margalit, Avishai (1992), Idolatry; trans. (from Hebrew) Naomi Goldblum (Cambridge: Harvard University Press).

Hass, Andrew W. (2013), Auden's O: The Loss of One's Sovereignty in the Making of Nothing (Albany: State University of New York Press).

Jullien, François (1991), Éloge de la fadeur: A partir de la pensée et de l'esthétique de la Chine (Arles: Éditions Philippe Picquier).

Jullien, François (1992), La propension des choses: Pour une histoire de l'efficacité in Chine (Paris: Seuil).

Jullien, François (1993), Figures de l'immanence. Pour une lecture philosophique du Yiking (Paris, Grasset).

Jullien, François (1995), Dialogue sur la morale (Paris: Grasset).

Jullien, François (2008), Les transformations silencieuses (Paris: Grasset).

Lao Zi, trans. D. C. Lau (1963), Tao Teh Ching (New York: Penguin Books).

---- trans. Arthur Waley (1997), Tao Te Ching (London: Wordsworth Editions Ltd).

---- trans. James Legge (1891), The Texts of Taoism 2 vol, (Oxford: Clarendon Press/ London: Humphrey Milford).

---- trans. Stephen Mitchell (1988), Tao Te Ching, or the Book of the Way (New York: Harper Collins).

Leupin, Alexandre (1989), Barbarolexis: Medieval Writing and Sexuality (Cambridge: Harvard University Press).

Magee, Glenn Alexander (2001), Hegel and the Hermetic Tradition (Ithaca: Cornell University Press).

Meng Zi, trans. Bryan W. van Norden (2008), Mengzi: With Selections from the Traditional Commentaries (Indianapolis: Hackett, 2008).

Merton, Thomas (1961), Mystics and Zen Masters (New York: Farrar, Straus and Giroux).

Zhang, Longxi 张隆溪 (1992), The Tao and the Logos: Literary Hermeneutics, East and West (Durham: Duke University Press). 